\title{
IAMJ
}

INTERNATIONAL

AYURVEDIC

MEDICAL JOURNAL

ISSN: 2320-5091

Impact Factor: 6.719

\section{A CLINICAL STUDY TO EVALUATE THE EFFECT OF TOPICAL APPLICATION OF CERTAIN INDIGENOUS DRUGS IN THE MANAGEMENT OF KIKKISA}

\author{
Dharitri Purohit ${ }^{1}$, Ramadevi G ${ }^{2}$, Arpana Jain ${ }^{3}$ \\ ${ }^{1}$ PG Scholar ${ }^{2}$ Professor \& HOD, ${ }^{3}$ Assistant Professor \\ Dept. of Prasuti Tantra \& Stree Roga, S.D.M College of Ayurveda Udupi, Karnataka, India
}

Corresponding Author: veda.purohit@gmail.com

https://doi.org/10.46607/iamj0809092021

(Published Online: September 2021)

Open Access

(C) International Ayurvedic Medical Journal, India 2021

Article Received: 24/08//2021 - Peer Reviewed: 04/09/2021 - Accepted for Publication: 05/09/2021

\section{Check for updates}

\begin{abstract}
The woman is the most artistic creation of our creator. She carries pride in her appearance $\&$ gains confidence by maintaining her beauty also is equally esteemed about motherhood. For every woman, pregnancy is the most important \& pleasurable phase of life, as this is the time she evolves as a mother. This comes with several inevitable changes in her appearance like weight gain, skin changes \& whatnot. Kikkisa is one such physiological skin changes of pregnancy. Kikkisa is a skin manifestation in 3rd trimester of pregnancy seen in about $90 \%$ of pregnancies. This is co-related with striae gravidarum presenting as stretch marks on abdomen, thighs and breasts associated with itching, burning sensation, dryness \& discolouration. Though not a disease, it does seek a lot of attention for the symptoms are very disturbing to women. Hence, an efficient \& easy method was selected in our study for treating kikkisa. Objectives: To assess the effect of the application of raktachandanadi churna with lakshadi taila over the abdomen in the management of kikkisa. Study design:30 pregnant women from 28 weeks of gestation diagnosed with kikkisa were selected \& given to apply Raktachandanadi churna with Lakshadi taila over abdomen half an hour before bath for 2 months. Result: After trial, marks became less prominent but not reduced completely. We found an effective reduction in symptoms like itching (93.1\%), dryness (95.45\%), burning sensation (78.6\%), \& discolouration $(57.6 \%)$, without causing any changes in the texture of the skin.
\end{abstract}

Keywords: Kikkisa, Striae gravidarum, Raktachandanadi churna, Lakshadi taila 


\section{INTRODUCTION}

Today, Ayurveda is the oldest form of medicine \& yet the most scientific \& practical one. Through it, man has learnt the prakruti (physiological constitution) \& vikruti (pathology of body constitution) of the body along with the means to maintain the prakruti \& cures for the vikruti. One such prakruta karma of human life is pregnancy, the most joyous \& pious journey in every woman's life. The vikruti most commonly expected in almost all women in this phase is kikkisa (striae gravidarum).

$90 \%$ of women develop kikkisa in the third trimester of pregnancy, around $45 \%$ may begin as early as 26 weeks. ${ }^{1}$ It is characterized by itching (kandumoola cha kikkisa) in udara (abdomen), sthana (breast) \& uru (thigh) Pradesh associated with a burning sensation (pani-pada daha), dryness \& discolouration of the skin. ${ }^{2}$ It is tridoshaja vyadhi which is caused by the accumulation of tridosha in urah Pradesh due to garbhotpeedanan (pressure from rapid fetal growth). Kikkisa is manifested in the form of linear striae (rekhakara) from breaking collagen bonds in the epidermis \& tearing up of epidermal layers (twak sphutana or vidarana). ${ }^{3}$ These marks though commonly seen in pregnancy bring agony to the population due to its cosmetic concern, as maintaining the structural integrity of her body \& beauty gives confidence to women. During pregnancy, the constant irritation caused by itching \& burning causes agony to the woman both physically \& mentally. Also, constant itching of the abdomen may induce premature contraction from local stimulation. In the post-partum period, the permanent remains of these marks are even agonizing as they distort her mental \& physical appeal in the public. Considering the cosmetic importance of the disease, treatment is necessary.

The study, Topical Application of Raktachandanadi Churna with Lakshadi Taila over abdomen was taken up. The results showed the drug was insignificant on the texture of the skin; significantly effective in reducing burning sensation \& discolouration of the skin; highly significant is reducing dryness \& itching over abdomen from kikkisa. It significantly reduced the marks \& brought back to normal skin tone but marks did not completely wear off.

OBJECTIVES: To assess the effect of raktachandanadi churna with lakshadi taila application on the abdomen for management of kikkisa.

REVIEW OF LITERATURE: Twak (skin) is sparshanendriya adhisthana ${ }^{4}$ (site of touch perception) and covers the entire body. It is the upadhatu of mamsa dhatu ${ }^{5} \&$ is developed from matruja bhava ${ }^{6}$ (maternal factor). It has got direct relation with all the dosha, dhatu and mala as it is the structural and functional unit of the body in direct contact with the external environment. Twacha is explained along with kikkisa as the disease harbours in twacha and according to Acharya Charaka kikkisa is formed on Avabhasini twacha.

The pathology of formation of striae is explained as the tearing up of the epidermal layers from breaking of collagen fibrils to expose the vascular dermis to the external environment and giving it a reddish or pinkish appearance.

All the acharyas have explained, kikkisa, $a^{7,9,10}$ in masanumasika garbhini lakshanas (months changes of pregnancy) as a skin change specific to pregnancy and occurs during the $7^{\text {th }}$ month. It is said to be caused by dislodged tridosha due to garbhotpeedana \& gets located in urah. This is associated with kandu, rukshata \& pani pada daha. The itching, as a rule, is kapha dushti lakshana but here it is also caused by the dryness of the skin and this dryness is a result of vata dushti. The complaint of burning sensation is developed due to dushita pitta. Kikkisa can be correlated to striae gravidarum ${ }^{11,12,13}$ as its symptoms, pathology and presenting symptoms are all similar. Like the-

-Location is abdomen, thighs and breast

-Pathology is due to the rapidly growing fetus which causes over-stretching of the abdomen leading to tearing of the skin

-Symptoms are itching, burning sensation and formation of linear marks on the skin.

Contemporary science has mentioned the 
physiological occurrence of stretch marks associated with itching \& burning sensation over the abdomen, breasts and thighs during pregnancy but has not studied much about its treatment, as physiological processes do not necessitate treatment. They only use lotions, essential oils and butter for reducing the associated complaints. But, in Ayurvedic classics, all the acharyas have given specific treatment plans both for internal and external administration to cure kikkisa $^{14,15}$ as they knew about even the cosmetic concern of the manifested disease for the women. Hence, treating these marks becomes important even from the cosmetic point of view.

About $90 \%$ of women develop these stretch marks during pregnancy which appear as pinkish linear marks on the skin associated with itching and burning sensation thought to be caused by over-stretching of the skin owing to the rapid growth of the abdomen to make room for the developing fetus. These marks later turn glistening white as the cause for overstretching is lost in the postpartum period. Hence to address this concern of the women, this study was taken to manage kikkisa with minimum external applications.

\section{METHODOLOGY:}

\section{1) Inclusion Criteria:}

Diagnosed cases of kikkisa

Age- 18-35 years

Pregnant woman with gestation of 28 weeks

\section{2) Exclusion criteria:}

Precious pregnancies

Pregnancy with a history of threatened abortion

Bad obstetric history

Obesity

Any kind of skin diseases

Systemic illness

\section{3) Assessment criteria:}

Table 1: Assessment parameter

\begin{tabular}{|l|l|}
\hline Subjective parameters & Itching \\
\cline { 2 - 2 } & Burning sensation \\
\hline Objective parameters & Discolouration \\
\hline & Dryness \\
\hline & Skin texture \\
\hline
\end{tabular}

Study Design: It is an open labelled clinical study with pre-test and post-test design. Wherein, 30 pregnant women in the age group of $18-35 \mathrm{yrs}$. who developed kikkisa were randomly taken for the study from OPD \& IPD of SDM Ayurveda Hospital, Udupi in their 28 weeks of gestation. The signs and symptoms of kikkisa were considered for diagnosis \& assessment. The 30 selected women were assessed before, during $\&$ after treatment $\&$ follow up was taken 1 month after completion of intervention \& were given topical application of Raktachandanadi churna ${ }^{16,17}$ mixed with Lakshadi taila ${ }^{18}$ over the abdomen for 2 months half an hour before bath. 


\section{OBSERVATIONS:}

Table 2: Distribution of patients based on demographic data-

\begin{tabular}{|l|l|l|l|}
\hline Variable & Category & Frequency & Percentage \\
\hline Age & $26-30$ & 12 & 40 \\
\hline Religion & Hindu & 22 & 73.3 \\
\hline Education & UG & 13 & 43.3 \\
\hline Occupation & Desk job & 11 & 36.7 \\
\hline Socio-economic status & Middle class & 17 & 56.7 \\
\hline
\end{tabular}

Graph 1: Distribution of patients based on Demographic data

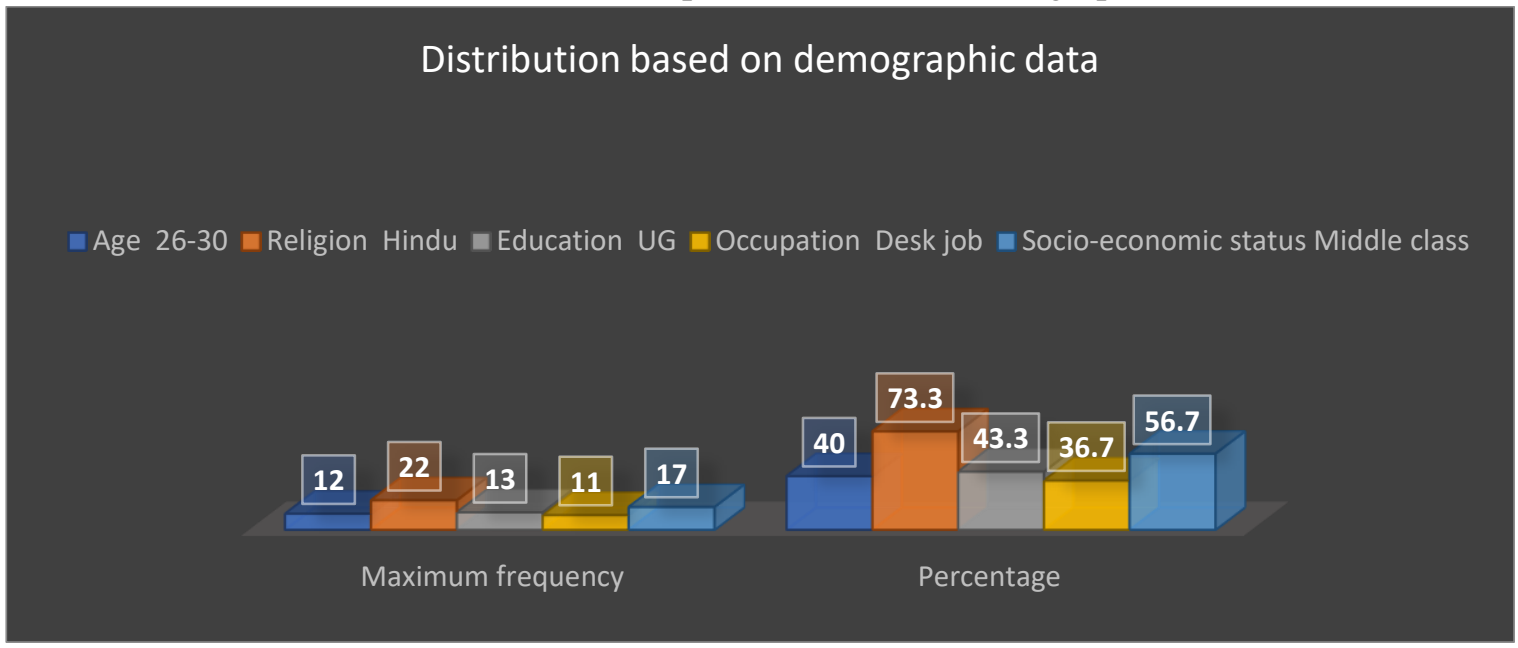

Among the 30 pregnant women included in the study, $40 \%$ were in the age group of 26-30 yrs. $25-30$ is the active reproductive age group with maximum fertility, it justifies the hype in no. of pregnant women in this age. Religion (73.3\% Hindus), Education (43.3\%-
Graduates), Occupation (36.7\%- Desk job workers) \& Socio-economic status (56.7\%- Middle-class society) do not warrant for occurrence or non-occurrence of kikkisa.

Table 3: Distribution of patients based on other parameters-

\begin{tabular}{|l|l|l|l|}
\hline Variable & Category & Frequency & Percentage \\
\hline Onset & 5-10 days & 19 & 63.3 \\
\hline Akruti & Madhyama & 13 & 43.3 \\
\hline Dietary habits & Veg & 16 & 53.3 \\
\hline Texture of skin & Normal skin & 11 & 36.7 \\
\hline Weight & $51-55 \mathrm{~kg}$ & 9 & 30 \\
\hline
\end{tabular}


Graph 2: Distribution of patients based on other parameters

\section{Distribution based on other parameters}

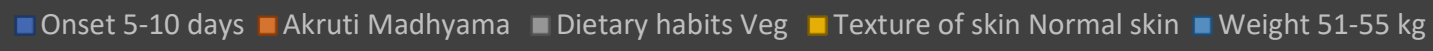

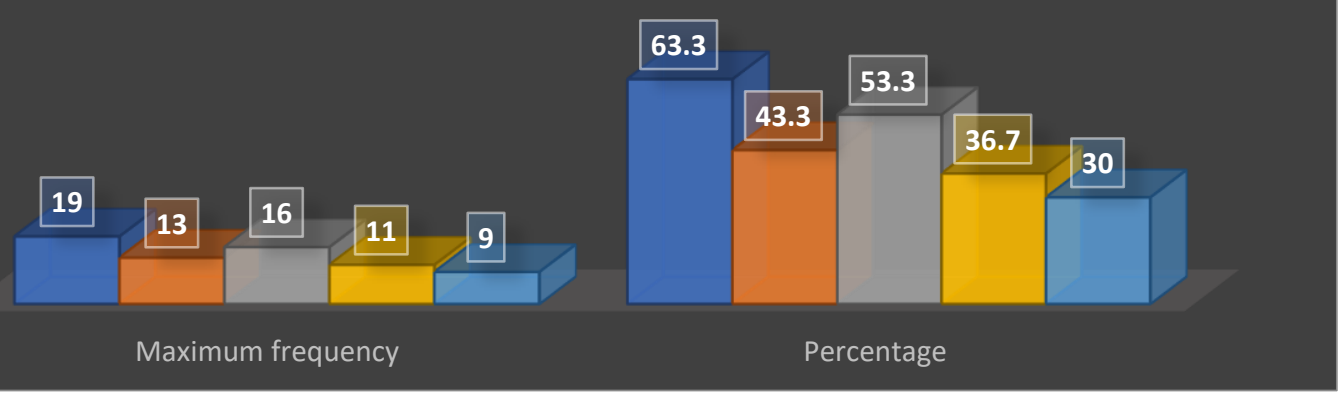

Among the 30 study subjects, $63.3 \%$ of women had developed symptoms 5-10 days before treatment, most of the patients (43.3\%) had madhyama deha akruti but the number \& intensity of symptoms were more in both sthoola \& krusha women when compared to madhyama akruti. Maximum patients were vegetarians but, diet does not seem to have any major relation with kikkisa. Women with normal \& soft textured skin did not show significant changes in the skin as much as the ones with rough skin. Probably constant oiling of the skin had reduced the roughness. The weight of women on inclusion did not seem to influence the development of stretch marks in pregnancy as the distribution was almost even. Probably because the increase in weight is the cause for the development of stretch marks in obese patients $\&$ not pregnancy.

\section{Distribution of patients based on prakruti-}

Maximum patients were pitta-vata prakruti i.e., 7, followed by kapha-pitta, pitta-kapha \& vata-pitta each $5 \& 4$ each were of kapha-vata \& vata-kapha prakruti. Indicating women of all prakruti were prone to develop kikkisa.

Graph 3: Distribution of patients based on Prakruti

\section{Distribution based on prakruti}
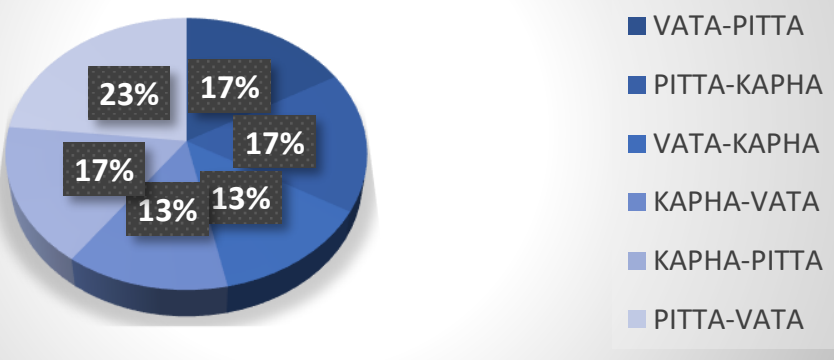


\section{Distribution based on vikruti-}

Out of the 30 included patients, 8 showed vata-kapha vikruti \& pitta-vata vikruti each, 5 had vata-pitta dushti lakshanas, 3 had pitta-kapha dushti, 4 had kapha-vata dushti \& the last two were of tridosha vikruti. With the predominance of vata, all the tridosha in permutation \& combination were involved in the development of kikkisa.

Graph 4: Distribution of patients based on Vikruti

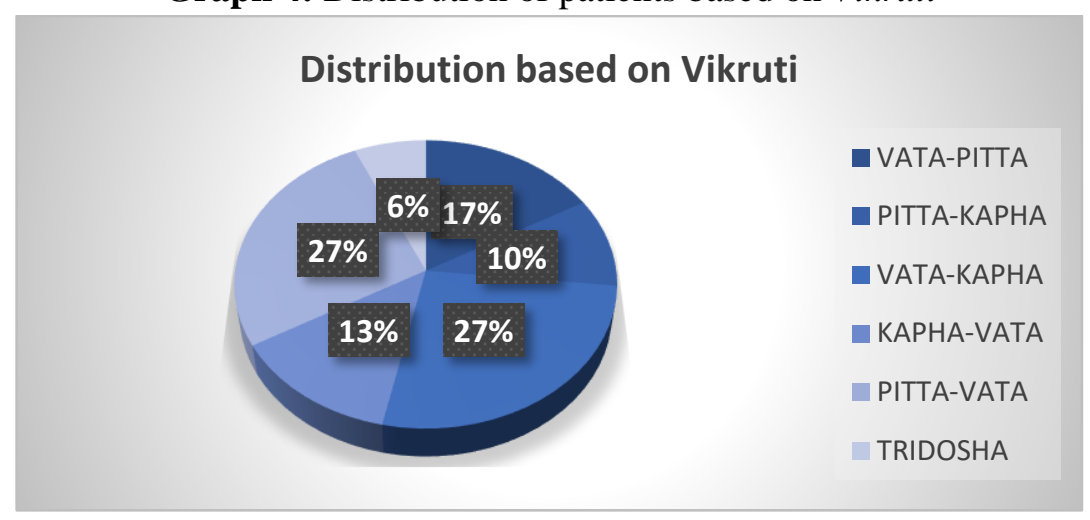

RESULT- Post-study the data was analyzed on SPSS Ver. 20 with Wilcoxon signed-rank test, for Before treatment during treatment, after treatment \& after follow up to analyze the effect of treatment on each of the symptoms of kikkisa.

Table 4: Statistical results of all the symptoms by Wilcoxon Signed Rank test

\begin{tabular}{|c|c|c|c|c|c|c|c|c|c|}
\hline \multirow[t]{2}{*}{ Symptom } & \multicolumn{3}{|c|}{ BT-1 ${ }^{\text {st }}$ month } & \multicolumn{3}{|c|}{ BT-AT } & \multicolumn{3}{|c|}{ BT-AF } \\
\hline & $\mathbf{Z}$ & $\mathbf{P}$ & & $\mathbf{Z}$ & $\mathbf{P}$ & & $\mathbf{Z}$ & $\mathbf{P}$ & \\
\hline Texture of Skin & -2.00 & 0.046 & S & -1.13 & 0.256 & NS & -0.49 & 0.620 & NS \\
\hline Itching & -2.12 & 0.034 & S & -4.20 & 0.000 & HS & -4.67 & 0.000 & HS \\
\hline Burning ensation & -2.44 & 0.014 & S & -2.50 & 0.012 & S & -3.00 & 0.003 & $S$ \\
\hline Dryness & -3.74 & 0.000 & HS & -4.13 & 0.000 & HS & -4.13 & 0.000 & HS \\
\hline Discolouration & -2.23 & 0.025 & $S$ & -3.36 & 0.001 & HS & -3.77 & 0.000 & HS \\
\hline
\end{tabular}

Effect on Texture of skin- the results showed no significant change in the texture of skin both after treatment (P-0.250) \& after follow-up (P-0.620). even clinically only 4 patients noticed changes in the texture of the skin.

Effect on Itching- the test results showed the trial drug was highly significant in treating itching at P0.000 both AT \& AF.

Effect on Burning sensation- very few patients presented with burning sensation but among them most was relieved from the complaint after treatment $\&$ test results showed the drug was significantly effective in reducing burning sensation bot AT (P0.012) \& AF (P-0.003).

Effect on Dryness- almost all the patients found significant relief from dryness post-treatment from the very beginning. Statistically, the drug was highly significant in reducing dryness after 1 month, AT \& AF at P-0.000.

Effect on Discoloration-discoloration of skin was reduced with highly significant results both AT (P$0.001) \& \mathrm{AF}(\mathrm{P}-0.000)$.

\section{DISCUSSION}

\section{Before Treatment:}

Distribution of Itching before treatment- Before treatment women had complaints of itching among which maximum i.e., $60 \%$ of women had moderate itching indicating that itching reduced on distraction, $26.7 \%$ had severe itching and $10 \%$ had mild itching 
meaning the complaint was only occasional. Itching is observed in maximum patients as it is manifested from dryness caused by overstretching of the skin. It is a manifestation of vitiated vata dosha.

Distribution of Burning sensation before treatment- On inclusion, 53\% of patients had burning sensation, $26.7 \%$ had a mild burning sensation, $16.7 \%$ had moderate and only $3.3 \%$ women had a severe burning sensation. Since kandu is the main symptom in kikkisa which leads to abrasions resulting in a burning sensation. The symptom is caused by involvement of vitiated pitta, one among the dosha vikruti in present condition and also twak is adhisthana for bhrajaka pitta so, burning sensation in the skin is seen.

Distribution of Dryness before treatment- among the 30 subjects, $46.7 \%$ had moderate dryness i.e., scaly appearance of the skin, $16.7 \%$ had mild dryness \& $10 \%$ had severe dryness i.e., dry and flaky appearance of skin. While $26.7 \%$ of women did not have any dryness probably due to Anupa desha and constant perspiration, the epidermis is constantly moistened, which may prevent drying up of skin. Dryness is again a result of overstretching and tearing up of collagen bonds in the corneocytes which opens the epidermal layer to the external environment and increased water loss.

\section{Distribution of Discoloration before treatment- a} total of 26 women complained of discolouration of the skin, but the colour reflected were different for different women. $36.7 \%$ had reddish discolouration, $26.7 \%$ had brownish-blackish discolouration and $23.3 \%$ had pinkish discolouration of the skin. Some women had discolouration only along the linear marks formed while some manifested blackish discolouration all over the abdomen like hyperpigmentation of skin(fig1).

The colour of the skin is reflected from the Avabhasini which is the first layer of skin and dosha vikruti in that layer leads to the development of kikkisa.
Fig 1- Before treatment

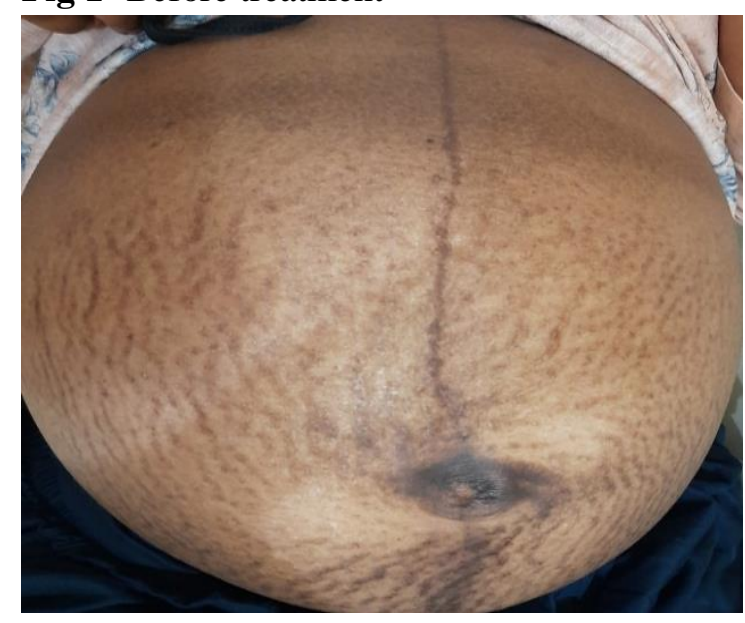

Fig 2- After treatment

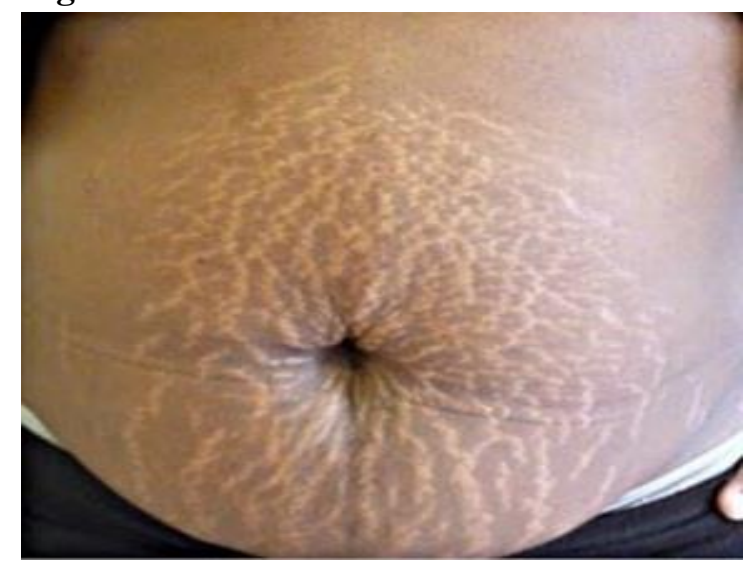

\section{Results After treatment:}

the length and thickness of the striae seemed to reduce. The colour of the marks reduced and came to near normal complexion in the striae gravidarum, but striae albicans in multis only showed a reduction in the whitish appearance.

\section{Effect on the texture of skin-}

The test result was insignificant in changing the texture of the skin, but clinically roughness and dryness were reduced in 4 patients, which is brought about by normalizing vitiated vata. This change may be attributed to the twachya and snigdha properties of the taila.

\section{Effect on itching over abdomen-}

The test results were highly significant statistically and clinically both after treatment and after follow up. Clinically the patients who had developed itching had 
found relief from the complaint. All the drugs used in this study had kandughna \& kushtaghna properties, as a result, alleviation of itching was quite effective.

\section{Effect on burning sensation-}

The burning sensation is the main feature of vikruta pitta. This was reduced completely in 11 out of the 14 patients. The drugs selected for the study were shita virya, kaphapitta shamaka, vatapittahara. Raktachandana, Musta, Chandana, Manjishta possess pittashamaka and dahaprashamana properties hence were effective in reducing the burning sensation. Statistically, the result was significantly effective in treating the symptom.

\section{Effect on the dryness of the skin-}

Statistically and clinically the trial drug was highly effective in treating dryness. All the patients who had developed dryness found complete relief from the 1stmonth follow-up itself and continued even after, indicating vatahara properties of the trial drugs. And the reduction in the dryness was not merely a temporary effect of the application of oil, but due to vatahara, twak prasadana \& snigdha, bruhmana properties of the drug.

\section{Effect on the discoloration of the skin-}

Among the 26 patients who had developed some degree of discolouration (pinkish, reddish, brownish or blackish), 21 women found a change in the colour and almost all of them had come back to normal skin complexion. 10 women who had developed blackish discolouration with thick indurations found reduction, $\&$ complete reduction was seen in 3 patients after treatment (fig2). As selected drugs were possessing varnya, twachya \& varna prasadana properties, they were effective in reducing the discolouration and normalize the Chaya \& Prabha.

\section{Probable mode of action of the drug-}

All the Acharyas have discussed vividly the treatment of kikkisa in the form of external administrations like lepa, seka, abhyanga etc. Compared to abhyanga \& seka, lepa can be considered as a better form of external administration as the time for which the drug is in contact with the skin is more. Thus, there is better scope for absorption of the drugs.

Vrana ropana and varna prasadana are one of the indications for use of lepana karma. According to acharya Sushruta, pradeha is the kind of lepa that can be made from either ushna or shita virya dravyas and is effective in vata-kaphaja vikara. The dose can be decided based on the Dosha dushti and even tanualpa matra dravya is effective in fulfilling the purpose. Lepa is mixed with Sneha dravya to bring it to the required consistency based on the dosha. Hence, lepana karma was chosen for the trial.

All the 4 ingredients selected for the study i.e., Raktachandanadi churna is from Charakokta Varnya or Kandughna dashemani.

Raktachandana ${ }^{19}$ being tikta rasatmaka, asra-pitta hara \& possess vranahara property. Its constituents like phenols, pterostilbene etc. act as antioxidants, anti-inflammatory, anti-microbial properties that help in healing twak sphutana, vrana ropana \& reduce the size of the marks.

Sariva $^{20}$ is included both in varnya \& kandughna gana. It is tikta rasatmaka tridoshahara dravya \& is widely used in all ranges of classical cosmetic products. It is proven for making skin even toned \& reduce pigmentation; with constituents like hemidesmin, triterpenes etc. which renders its antiacne, antioxidant, anti-microbial \& wound healing properties \& help in reducing discolouration, bring back the normal colour \& texture of the skin.

Haridra $^{21}$ containing curcumin, curcuminoids etc. is the most widely accepted cosmetic ingredient for its anti-oxidative, immune-modulatory, cleansing, antiseptic, wound healing properties. It is mentioned in kandughna \& kushtaghna ganas in Charaka. As it is katu tikta rasatmaka, ushna virya dravya which possesses varnya, twakdosha hara vrana ropana \& kandughna properties. These, help in reducing itching $\&$ healing the epidermal layers of the skin.

Manjishta ${ }^{22}$ is one of the varnya, raktaprasadana, daha prashamana dravya composed of manjistin, rubifoline etc. which possesses properties of antiinflammatory, detoxifying, analgesic, anti-pyretic, anti-microbial. It helps to reduce burning sensation \& to normalize the skin tone \& complexion with its natural pittashamaka, jwarahara karma.

The ingredients of Lakshadi taila ${ }^{23,24}$ possess varnya, 
kandughna \& kushtaghna properties. Laksha along with this is endowed with baghna-sandhana guna which adds to the healing of broken collagen bonds \& normalizes the breaks formed in the epidermis to reduce the size of kikkisa. This taila is prepared in tila taila base, which itself is twachya, twak dosha hara \& shreshta among all sneha dravyas for cosmetic use. This taila, when used with Raktachandanadi Churna helps in the reduction of itching \& dryness due to its snigdha guna, madhura rasatmaka, vata hara dravyas like Yashtimadhu, Ashwagandha, Rasna etc. These are composed of potentially effective antidepressant, immunomodulatory, antiinflammatory \& anti-stress actions, which helps in reducing dryness of the skin by reducing serotonin receptivity of skin \& enhancing proliferation of tissues \& increase collagen synthesis. Dravya like Chandana, Musta, Raktachandana possess shita virya, asrapittahara, jwara daha prashamana properties \& have potential antipyretic, antiseptic, diuretic, antiscorbutic etc. properties which are effective in the management of burning sensation \& wound healing. Twachya, varna prasadana, vranaropana properties of Haridra, Sariva, Tila, Laksha \& Kushta helps in effectively reducing the discolouration $\&$ maintains the normal complexion of the skin.

Most of the ingredients of the trial drug were potentially anti-inflammatory, anti-oxidative, antibacterial \& and histaminic properties which at the level of skin helps to heal the visible wounds \& the various insensible injuries that skin undergoes every day. These rejuvenate skin $\&$ maintain normal tone $\&$ texture of the skin. The drugs with potential antihistamines increase the proliferation \& differentiation of keratinocytes thereby, maintaining the integrity of the tissues to prevent tissue breakdown \& tearing. Added to this, various studies have shown that drugs like Ashwagandha, Yashtimadhu etc. which are highly effective antidepressants; reduce drying up of skin \& its resulting itching by reducing the receptivity of skin for serotonin.

\section{CONCLUSION}

The clinical trial showed quite a few positive resultsOn itching- the test results \& the clinical results were highly significant in reducing itching associated with striae in two months. Some patients even found relief within few days of the application. While some who complained of intense itching voluntarily requested to apply twice.

On burning sensation- Among the $53 \%$ of subjects who had developed burning sensation along with kikkisa, 11 women had found complete relief. Statistically trial was effective in treating burning sensations.

On dryness of skin- The results showed the drug was highly effective in reducing dryness in both clinical \& statistical results. All the patients who had developed dryness had found relief.

On discolouration $-80 \%$ of women with a complaint of discolouration found a noticeable change in the colour \& the marks had nearly matched to normal skin colour. Results showed the drug was significantly effective. Primigravidae with tense skin enjoyed more relief from discolouration. The pre-existing marks in the multi did not cause any discomfort and showed minimal changes after completion of the trial.

On Texture of skin- Tests showed insignificant results of the drug in changing the texture of the skin. Clinically as well, the change in the skin texture was not quite admirable.

Finally, conclusions are drawn from the entire workup of the study \& the statistical results that the combination of the trial drug was effective in reducing the symptoms associated with kikkisa, but the marks were not completely reducible. Probably, if the drug was studied further for its effectiveness in the prevention of kikkisa; it may be more effective \& fruitful for the population.

\section{REFERENCES}

1. Boichier A D. Ian, Ellis Harold, Fleming R Peter, French's Index of differential diagnosis, Butterworth Heineman: Oxford, Ed- 13 ${ }^{\text {th }}, 1997$, Pg- 637.

2. Acharya Vagbhata, Astanga Samgraha, with Hindi commentary edited by Kaviraj Atrideva Gupta. 
Published by Krishnadas Academy, Varanasi. Reprinted in 1993. Pp - 408, page no - 282,283.

3. Amarakosa, Ramasarami commentary of Bhanavaji Dixit Pt Hargovinda shastry, Chaukhamba Sanskrit Samhita publishers, Varanasi. 3rd edition, 1997. page no- 168.

4. Agnivesha. Charaka Samhita, Chakrapani Commentary. Ed. Acharya Yadavji Trikamji, Varnasi: Chaukambha Orientalia, 2011; Sutrasthana; Ch- 8, verse -10, Pg- 56.

5. Agnivesha. Charaka Samhita, Chakrapani Commentary. Ed. Acharya Yadavji Trikamji, Varnasi: Chaukambha Orientalia, 2011; Chikitsasthana; Ch15, verse - $17, \mathrm{Pg}-514$.

6. Agnivesha. Charaka Samhita, Chakrapani Commentary. Ed. Acharya Yadavji Trikamji, Varnasi: Chaukambha Orientalia, 2011; Shareerasthana; Ch15, verse - $17, \mathrm{Pg}-514$.

7. Acharya Vagbhata, Astanga Samgraha, Hindi teeka, Ed.- Kaviraj Atrideva Gupta, Varanasi: Krishnadas Academy, Reprint-1993, Pp - 408, page no - 282, 283.

8. Agnivesha, Charaka Samhita, Ayurveda Dipikas ayusi- commentary, Ed.- Vd. Harish Chandra Sing kushwaha. Varnasi: Chaukamba orientalia, $1^{\text {st }}$ edition, 2005. Pp - 964, page no - 867,868.

9. Bhela Samhita, edited by Prof. Priyavat Sharma, published by Chaukhamba Visvabharati Varanas, 1st edition 2000, Pp - 372, page no - 243.

10. Vaidya Jadavji Trikramji Acharya, Editor. Chakrapanidatta commentary of Agnivesh revised by charaka, Dridhabala on Charaka Samhita, shareera sthana; jatisutriya shareeram; chapter 8 , verse 32 . Varanasi: Chaukambha Orientalia;2011; Pg-346.

11. Marks Ronald \& Richard Motley. Roxburgh's Common skin diseases. London: CRC Press Pvt Ltd, 2011; Ch- 17, Pg- 251-53.

12. HiralalKonar, Dutta D.C. D.C.Dutta's Textbook of Obstetrics, 8th edition, New Delhi: Jaypee the health sciences publisher (p) Ltd; 2015; P56-57.

13. Cunningham, Leveno, Bloom, Dashe, Hoffman, Casey, Spong. William's obstetrics, 25th edition, McGraw Hill education: 6, Ch4, P 44-45.

14. Pt. Bishagacharya H P. Krishna R S N, Editor. Dr Anna M K, Arunadatta, Hemadri commentary on Vagbhata. Ashtangahrudayam, shareera sthana, chapter 1, verse 58. Varanasi: Chowkambha Krishnadas Academy, P-372.

15. Vaidya Jadavji Trikramji Acharya, Editor. Chakrapanidatta commentary of Agnivesh revised by charaka, Dridhabala on Charaka Samhita, shareera sthana; jatisutriya shareeram; chapter 8 , verse 32 . Varanasi: Chaukambha Orientalia;2011; Pg No.-346.

16. Acharya Agnivesa, Charaka Samhita, chakrapani teeka edited with Charaka-Chadrika, Hindi commentary, by Dr Brahmanand Tripathi. Sutrasthana, ch- 4, verse- 11 (14), pg-32.

17. Acharya Agnivesa, Charaka Samhita, chakrapani teeka edited with Charaka-Chadrika, Hindi commentary, by Dr Brahmanand Tripathi. Sutrasthana, ch- 4, verse- 11 (14), pg-33.

18. Panditrao, D V, Nayar, Sharada. Sahsrayoga, Ed.- Dr. Mahendrapala Singh. New Delhi: CCRAS. Taila prakarana, verse- 104, Pg-284-85.

19. Lucas S K, Dravyaguna_vijnana, Vol II. Varnasi: Chaukambha Vishwabharati, 2017; Ch-1, pg- 219-23.

20. Lucas S K, Dravyaguna_vijnana, Vol II. Varnasi: Chaukambha Vishwabharati, 2017; Ch-2, pg- 542-43

21. Lucas S K, Dravyaguna_vijnana, Vol II. Varnasi: Chaukambha Vishwabharati, 2017; Ch-1, pg- 275-79.

22. Lucas S K, Dravyaguna_vijnana, Vol II. Varnasi: Chaukambha Vishwabharati, 2017; Ch-1, pg- 411-14.

23. Kaviraj Govind D S, Bhaishajyaratnavali. Ed.- prof. Mishra S N, Varnasi: Chaukambha surbharati Prakashan; 2005; Ch- 71, verse- 150-51, pg-1091-92.

24. Chakrapanidatta, Chakradatta. Ed.- prof. Ramanath Dwivedy. Varnasi: Chaukambha Sanskrit bhawan. 2014. Ch- 64, verse- 77-78, Pg- 401.

\section{Source of Support: Nil Conflict of Interest: None Declared}

How to cite this URL: Dharitri Purohit et al: A Clinical Study To Evaluate The Effect Of Topical Application Of Certain Indigenous Drugs In The Management Of Kikkisa. International Ayurvedic Medical Journal \{online\} 2021 \{cited September 2021\} Available from: http://www.iamj.in/posts/images/upload/1974_1983.pdf 